\title{
ADAPTATION OF PROGENIES/CULTIVARS OF ARABICA COFFEE (Coffea arabica L.) IN MOUNTAINOUS EDAFOCLIMATIC CONDITIONS
}

\author{
Cesar Abel Krohling ${ }^{1}$, José Braz Matiello²; Saulo Roque de Almeida ${ }^{3}$, Frederico Jacob Eutrópio ${ }^{4}$, \\ Carlos Henrique de Siqueira Carvalho ${ }^{5}$
}

(Received: June 12, 2017; accepted: September 27, 2017)

\begin{abstract}
Brazil is known for production and worldwide export of coffees. Study of adaptation of new progenies/cultivars of Arabica coffee (C. arabica L.) with resistance to rust in mountainous edaphoclimatic conditions is important for crop renewal and also for new plantations. This study was performed in the mountainous region of the Espírito Santo state, Brazil, with 30 progenies/cultivars of Arabica coffee planted at $2.5 \times 0.7 \mathrm{~m}$ spacing with four replicates and seven plants/plot. The objective of the study was to evaluate the adaptation of rust-resistance coffee genotypes and compare them with the standard cultivars (Yellow and Red Catuaís), with regards to the characteristics of productivity, rust infection, productivity, sieve, aspect, plant vigor and yield according to the different maturity periods of the fruits. The results show that there are progenies/cultivars available with yields superior to Red and Yellow Catuais for the five different maturation periods. The progenies/cultivars present tolerance/resistance to rust, high plant vigor and good agronomic characteristics of the beans. These are options for new plantations or for renovation of crops for high harvest yield and do not required the use of pesticides.
\end{abstract}

Index terms: Productivity, rust, plant vigor, yield, sieve.

\section{ADAPTAÇÃO DE PROGÊNIES/CULTIVARES DE CAFÉ ARÁBICA (Coffea arabica L.) EM CONDIÇÕES EDAFOCLIMÁTICAS DE MONTANHAS}

RESUMO: O Brasil tem destaque na produção e exportação mundial de cafés. O estudo da adaptação de novas progênies/ cultivares de café arábica $(C$. arabica L.) com resistência à ferrugem nas condições edafoclimáticas das Montanhas é importante para renovação de lavouras e também para novos plantios. O estudo foi realizado na Região de Montanhas do Espírito Santo com 30 progênies/cultivares de café arábica plantados no espaçamento de $2,5 \times 0,7 \mathrm{~m}$ com quatro repetições com sete plantas/ parcela. $\mathrm{O}$ objetivo do estudo foi avaliar a adaptação dos genótipos com resistência à ferrugem do cafeeiro, comparando-as com as cultivares padrão (Catuaís Amarelo e Vermelho), nas características de produtividade, infecção de ferrugem, rendimento, peneira graúda, aspecto, vigor vegetativo e rendimento de colheita conforme as diferentes épocas de maturação dos frutos. Os resultados evidenciam que existem à disposição dos cafeicultores progênies/cultivares com produtividades superiores aos Catuaís Vermelhos e Amarelo nas cinco diferentes épocas de maturação. As progênies/cultivares apresentam tolerância/ resistência à ferrugem, alto vigor vegetativo e boas características agronômicas dos grãos e são opções para novos plantios ou para renovação de lavouras para alto rendimento de colheita e podendo dispensar o uso de agrotóxicos.

Termos para indexação: Produtividade, ferrugem, vigor vegetativo, rendimento, peneira.

\section{INTRODUCTION}

Arabica coffee (Coffea arabica L.) is cultivated in several producing-regions throughout Brazil with variable edaphoclimatic characteristics that play an important role in adaptation of the cultivars. The genotype $\mathrm{x}$ environment interaction determines the recommendation of the cultivar for each specific region (NASCIMENTO et al., 2010, MATIELLO et al., 2016).

Genetic breeding studies of coffee cultivars by several research organizations have promoted advances in coffee activity and its practical application by coffee growers (CARVALHO et al., 2008; PARTELLI et al., 2009), seeking an increase in productivity (MARTINEZ et al., 2007;
CARVALHO et al., 2010; MATIELLO et al., 2016) and greater resistance to rust. Rust is the main disease of Arabica coffee and depending on the spacing, cultivar and crop management can cause significant production losses (ZAMBOLIM et al., 2005; FAZUOLI et al., 2007; ANDREAZI et al., 2015).

Currently most of Brazil's coffee production is composed of cultivars presenting excellent agronomic characteristics, however with no resistance to rust. Utilization of rust-resistant cultivars avoids the use of agrochemicals, which reduces the risks of intoxication of the applier, environmental contamination, and reduces production costs (OLIVEIRA, et al. 2015; MATIELLO et al., 2016). It is also important

\footnotetext{
${ }^{1}$ Instituto Capixaba de Pesquisa, Assistência Técnica e Extensão Rural/ INCAPER - ELDR - Rua Arthur Haesse, 124, sala 201 29.255-970 - Marechal Floriano - ES - cesar.kro@hotmail.com

2,3,6 Fundação Procafé - Alameda do Café, 1000 - Jardim Andere - 37.026-400 - Varginha - MG - jbmatiello@gmail.com, sauloroquedealmeida@yahoo.com.br, carlos.carvalho@embrapa.br

${ }^{4}$ Faculdade Multivix Campus Cariacica - Rua 13 de maio, n 40 - São Geraldo - Cariacica - ES - 29.146-672 - eutropiofj@gmail.com
} 
to highlight that the Brazilian coffee agriculture faces high costs and lack workers of manual labor (SERA et al., 2015; MATIELLO et al., 2016).

The existing cultivars are classified into very early, early, middle, late and very late maturity cycles, which is a polygenic characteristic influenced by the environmental conditions, such as the region, local edaphoclimatic conditions, exposure direction, nutrition and biotic agents (GUERREIRO-FILHO et al., 2008; CARVALHO, 2008; RODRIGUES et al., 2014; RODRIGUES et al., 2016; MARTINS et al., 2017). Therefore, varieties with different maturation periods allow harvest scheduling, and those that increase the crop yield and have desirable agronomic characteristics should be prioritized when selecting the crop for implementation.

Several Arabica coffee cultivars were recently introduced and registered for use by coffee growers, however there are few studies on the behavior of these new genotypes in the field (PAIVA et al., 2010), especially when considering a period of 10 consecutive harvests in mountainous conditions. However, we know that prior to the use of these cultivars in commercial areas it is recommended that adaptability studies be done in the different coffee producing regions to evaluate their behavior in local soil and climate conditions for productivity and resistance to rust, and other characteristics.

The objective in this study was therefore to evaluate the adaptation of new progenies/cultivars of Arabica coffee (C. arabica) with resistance/ tolerance to coffee rust in edaphoclimatic conditions of the mountainous region of the state of Espírito Santo during 10 consecutive harvests. Comparisons were made with the standard cultivars (Red and Yellow Catuaí) with regards to the characteristics of productivity, rust infection, yield, sieve, aspect, plant vigor and harvest yield, according to the maturation times of the fruits.

\section{MATERIAL AND METHODS}

\section{Description of the study area, Cultivars and Cultural Treatments}

The study was carried out at the farm "Sítio Santa Maria" (coordinates: Lat: -20.4425 S, Long: $-40.7796 \mathrm{~W}$ and elevation of $717 \mathrm{~m}$ ), located in the municipality of Marechal Floriano, in the mountainous southeastern region of the Espírito Santo state. The soil is classified as Red Yellow Latosol (RYL) (EMBRAPA, 2013) and the climate is tropical with dry winter and summer rains, of the Aw type and subtype, according to the Köppen classification (Table 1).
The experiment was set up in a randomized block design with 30 treatments (progenies/ cultivars), four replicates and seven plants/plot planted in April, 2003 at a spacing of $2.5 \times 0.7$ $\mathrm{m}$ (densified). The thirty progenies/cultivars and selections used were thus classified according to the three maturation seasons (Table 2).

Cultural treatments of the crop during the study included liming and fertilization according to the soil analysis conducted every two years and the expected productivity, according to recommendations (PREZOTTI et al., 2007). Two foliar fertilizations with Boron (B), Manganese $(\mathrm{Mn})$ and Zinc (Zn) micronutrient salts were performed per year, two foliar applications of Copper hydroxide $(\mathrm{Cu})(45 \% \mathrm{Cu}$ metal $)$ were associated with the salts and an annual application of the insecticide thiamethoxan applied via soil drenching at the dose of $1.0 \mathrm{~kg} / \mathrm{ha}$ of the commercial product Actara WG for control of leaf miner. Management of the weeds was conducted manually with one mowing and two chemical treatments with the active ingredient Glyphosate at the dose of $1.0 \mathrm{~L} /$ ha of the commercial product Roundup. No specific rust control or irrigation was used. All evaluations were carried out in the five central plants of the four plots described below.

\section{Productivity, Yield, Sieves and Aspect}

Harvest was always performed manually on a sieve or canvas. Mean samples of $2.0 \mathrm{~kg}$ of harvested coffee were obtained from each plot and taken to pre-drying in a drying oven and final drying on a cement yard according to the climatic conditions of the season until reaching the moisture content between 11.5 and $12 \%$. Once dry, the samples were weighed, pulped and the yield (kilograms of processed coffee/kilograms of coffee beans) and productivity in processed coffee bags/hectare (sc/ha) were determined. The productivity yield was calculated for the 10 years of study and also the averages of the five biennia, i.e., 2005-2006, 2007-2008, 2009-2010, 20112012 and 2013-2014.

Next, 100 gram samples were classified on a set of sieves specific for the classification of coffee with regards to size of the raw beans, which were classified into only two groups: sieve 17 and above for the coarse flat type beans (BRAZIL, 2003). Aspect of the beans was evaluated by grading on a scale of 5 to 10 by three coffee buyers from the region with experience in the coffee trade. 
TABLE 1 - Climatic characteristics (2003-2014), including: Precipitation (mm), Relative Humidity (R.H.) (\%) and maximum and minimum Temperature $\left({ }^{\circ} \mathrm{C}\right)$ according to the mini meteorological station of the brand La Crosse and model Pro WS at the "Sítio Santa Maria" farm, Marechal Floriano, ES.

\begin{tabular}{cccccc}
\hline \multirow{2}{*}{ Year } & $\begin{array}{c}\text { Precip. } \\
(\mathrm{mm})\end{array}$ & Max & Min & Max & Min \\
\cline { 3 - 6 } & 1279.0 & 93.2 & 54.3 & 25.6 & 16.4 \\
2003 & 2138.0 & 92.5 & 55.3 & 25.4 & 16.2 \\
2004 & 1990.0 & 91.7 & 53.1 & 25.8 & 16.7 \\
2005 & 1568.0 & 92.6 & 54.8 & 25.4 & 16.3 \\
2006 & 1351.0 & 91.5 & 55.6 & 26.1 & 16.6 \\
2008 & 2409.0 & 93.8 & 55.3 & 25.4 & 16.2 \\
2009 & 2308.0 & 91.1 & 56.1 & 25.3 & 16.5 \\
2010 & 1716.0 & 93.2 & 54.3 & 25.9 & 16.6 \\
2011 & 1843.6 & 93.1 & 57.5 & 25.3 & 16.6 \\
2012 & 2126.9 & 90.8 & 52.9 & 26.4 & 16.7 \\
2013 & 1888.0 & 91.4 & 55.8 & 25.5 & 16.1 \\
2014 & 1304.0 & 94.2 & 53.9 & 26.0 & 16.4 \\
\hline Mean & 1826.8 & 92.4 & 54.9 & 25.7 & 16.4 \\
\hline
\end{tabular}

TABLE 2 - Progenies/cultivars of Coffea arabica L. and their respective characteristics of genealogy, maturation period, expected reaction to rust and vigor in the experiment installed at the "Sítio Santa Maria" farm, in Marechal Floriano, ES.

\begin{tabular}{|c|c|c|c|c|}
\hline $\begin{array}{l}\text { Progenies/ } \\
\text { cultivars }\end{array}$ & Genealogy & $\begin{array}{l}\text { Maturation } \\
\text { Period }\end{array}$ & $\begin{array}{l}\text { Reaction } \\
\text { to rust }\end{array}$ & Vigor \\
\hline Catucaí V. 785 Cv.15 & Icatu x 'Catuaí' (natural cross) & Very early & ++ & High \\
\hline Tupi IAC 1669-33 & $\begin{array}{c}\text { Vila Sarchi' x Híbrido de Timor } \\
\text { CIFC } 832 / 2\end{array}$ & Early & + & Medium \\
\hline Katipó & Catimor (245-3-7)- derivado & Early & ++ & Medium \\
\hline Caturra A. Colombiano & Caturra x Hibrído de Timor & Early & ++ & Medium \\
\hline Iapar 59 & $\begin{array}{l}\text { Villa Sarchi (CIFC 971/10) x } \\
\text { Híbrido de Timor (CIFC 832/2) }\end{array}$ & Early & + & Medium \\
\hline Caturra A. Seleção CAK & Bourbon' (natural mutation) & Early & +++ & Medium \\
\hline Caturra A. Seleção Nanicão & Bourbon' (natural mutation) & Early & +++ & Medium \\
\hline Catucaí A. 2 SL & Icatu x ‘Catuaí” (natural) & Medium & ++ & High \\
\hline Sabiá Cv. 708 & Catimor UFV 386 x Acaiá' & Medium & ++ & High \\
\hline Catucaí A. 24/137 Cv. 250 & Icatu x ‘Catuaí’ (natural) & Medium & ++ & High \\
\hline Catucaí V. 24/137 & Icatu x “Catuaí” (natural) & Medium & ++ & High \\
\hline IBC-Palma 2 (Fruto grande) & $\begin{array}{c}\text { Catuaí Vermelho IAC-81 x } \\
\text { 'Catimor UFV 353' }\end{array}$ & Medium & ++ & High \\
\hline Catucaí-açú (Fava grande) & Icatu x 'Catuaí”' (natural cross) & Medium & ++ & Medium \\
\hline Catucaí A. 24/137 - CAK & Icatu x ‘Catuaí” (natural) & Medium & ++ & High \\
\hline Catucaí A. (Fava grande) & Icatu x 'Catuaí” (natural) & Medium & ++ & High \\
\hline
\end{tabular}

Coffee Science, Lavras, v. 13, n. 2, p. 198 - 209, apr./jun. 2018 


\begin{tabular}{|c|c|c|c|c|}
\hline Catucaí V.20/15 Cv. 626 & Icatu x 'Catuaí'” (natural) & Medium & ++ & High \\
\hline Topázio MG 1190 & Catuaí Amarelo x Mundo Novo & Medium & +++ & High \\
\hline Rubi MG 1192 & Catuaí x Mundo Novo & Medium & +++ & High \\
\hline Catucaí V. 36/6 & Icatu x 'Catuaí'” (natural) & Medium & ++ & High \\
\hline Catucaí A. Cv. 07 - SSP & Icatu x ‘Catuai’” (natural) & Medium & ++ & High \\
\hline Mundo Novo 379-19 & Sumatra x Bourbon Vermelho & Medium & +++ & High \\
\hline Paraíso A. MG H 419-1 & $\begin{array}{c}\text { Catuaí Amarelo IAC-30 x Híbrido } \\
\text { de Timor UFV 445-46 }\end{array}$ & Medium & + & Medium \\
\hline Catucaí V. 19/08 Cv. 380 & Icatu x 'Catuaí' (natural) & Late & ++ & High \\
\hline Sarchimor Amarelo & $\begin{array}{c}\text { Catuaí Amarelo x Obatã V. IAC } \\
1669-20\end{array}$ & Late & + & Medium \\
\hline Catuaí A. IAC-39 & $\begin{array}{c}\text { Caturra A. IAC 476-11 x 'Mundo } \\
\text { N. IAC 374-19' }\end{array}$ & Late & +++ & High \\
\hline Catuaí V. IAC-99 & $\begin{array}{c}\text { Caturra A. IAC 476-11 x 'Mundo } \\
\text { N. IAC 374-19' }\end{array}$ & Late & +++ & High \\
\hline Catuaí V. IAC-81 & $\begin{array}{c}\text { Caturra A. IAC 476-11 x 'Mundo } \\
\text { N. IAC 374-19' }\end{array}$ & Late & +++ & High \\
\hline Catuaí V. IAC-44* & $\begin{array}{c}\text { Caturra A. IAC 476-11 x 'Mundo } \\
\text { N. IAC 374-19' }\end{array}$ & Late & +++ & High \\
\hline Acauã & $\begin{array}{c}\text { Mundo N. IAC } 388-17^{\prime} \text { x } \\
\text { Sarchimor IAC } 1668\end{array}$ & Very late & + & High \\
\hline Obatã V. IAC 1669-20 & $\begin{array}{l}\text { Villa Sarchi x Híbrido de Timor } \\
\text { (CIFC 832/2) }\end{array}$ & Very late & + & High \\
\hline
\end{tabular}

\section{Rust infection}

Evaluation of the incidence of rust on coffee leaves was carried out in the years 2010 to 2014, in the middle third and in the $3^{\text {rd }}$ and $4^{\text {th }}$ pair of leaves of the five central plants always at the time of harvest. Eight leaves were randomly collected per plant from the productive plagiotropic branches of 05 plants/plot, consisting of four leaves from two branches on the north face and four leaves from two branches on the south face, for a total of 40 leaves per plot (LIMA, 1979). The incidence of rust was assessed visually in the field by quantifying the percentage of leaves presenting pustules in relation to the total.

\section{Plant vigor}

The evaluation of plant vigor of the cultivars was carried out in the field, where scores from 1 to 10 were attributed, in which 10 corresponded to plants with the best development and greatest plant vigor. The scores were based on the general aspect of plant vigor, including: plant height, foliage, branch and crown growth, diameter of the orthotropic and plagiotropic branches (SHIGUEOKA et al., 2014).

\section{Harvest yield}

The harvest yield was evaluated only in 2009 during the fifth harvest, when the plants were at the peak of production, i.e., the highest average of the 10 years. The time spent to manually harvest the five (\%) central plants of the plot by two (2) well-trained harvesters in carried sieves was measured, one at the top and the other at the bottom of the plots. The coffee was measured and the number of 80 liter sacs/day that a worker was able to harvest for each progeny/cultivar was calculated.

\section{Statistical analysis of the data}

For analysis of productivity data of the years and biennials, the rust infection percent, yield, sieve 17 and above, aspect and plant vigor, 
an ANOVA was performed along with the ScottKnott test at $5.0 \%$ significance by the program SISVAR (FERREIRA, 2011). The Principal Component Analysis (PCA) was used to evaluate the characteristics of productivity, rust infection, yield, sieve 17 and above, plant vigor and harvest yield (sacks/day) by the program Fitopac 2.1.2.85.

\section{RESULTS AND DISCUSSION}

\section{Yield}

Significant differences were observed between the progenies/cultivars evaluated for productivity (both for the years and the bienniums), rust percentage, yield, sieve 17 and above, aspect and vigor, indicating genetic variability among the studied materials (Table 3 ).

The average yields of the five biennia increased significantly from $19.36 \mathrm{sc} / \mathrm{ha}$ in biennium 1 to $59.27 \mathrm{sc} / \mathrm{ha}$ in biennium 3 (Table 3). Mean productivity of the 10 harvests evaluated in this study was $45.66 \mathrm{sc} / \mathrm{ha}$, greater than that found by Costa et al., (2013) when evaluating the productivity of 14 progenies/cultivars of Arabica coffee during four harvests in southern Minas Gerais $(37.6 \mathrm{sc} / \mathrm{ha})$. The mean productivity of the progenies/cultivars evaluated over the years increased significantly from 2005 (18.2 sc/ha) to reaching its maximum in the fifth harvest in 2009 (76.8 sc/ha). After this point there was a stabilization of the mean productivities that always remained above $40.0 \mathrm{sc} / \mathrm{ha}$ (Table 3 ).

When analyzing the mean productivity from biennium to biennium, the formation of different groups (from 4 to 9 groups) was observed by the Scott-Knott test, and in the average of the 10 harvests nine groups were formed (Table 4). Costa et al., (2013) evaluated the productivity of fourteen Arabica coffee progenies/cultivars during four harvests in the southern region of Minas Gerais, observing the formation of four groups by the Scott-Knott test at 1\% probability.

In groups nine (a), eight (b) and seven (c) the less productive varieties are present, namely: Paraíso A. MG H 419-1 with medium maturation period and yield of $27.4 \mathrm{sc} / \mathrm{ha}$, variety Caturra A. (Sel. Nanicão) with early maturity and yield of $33.3 \mathrm{sc} / \mathrm{ha}$ and the Caturra A. (Sel. CAK) variety with early maturity and yield of $35.9 \mathrm{sc} / \mathrm{ha}$.

In group six (d) are the cultivars Iapar 59 and Mundo Novo 379-19 with mean productivities of 37.7 and $39.2 \mathrm{sc} / \mathrm{ha}$, with early and medium maturation, respectively. Group five (e) includes cultivars Caturra A. Colombiano and Katipó, both with early maturation and averages yields of 41.9 and $42.0 \mathrm{sc} / \mathrm{ha}$, respectively, as well as the progeny Catucaí A. Cv.07-SSP with average yield of 42.6 sc/ha and medium maturity.

In group four (f) there are six progenies/ cultivars, including the cultivars Catuaí V. IAC-44 of late maturation and Catucaí A. (Fruto grande), Catucaí V. 36/6, Rubi MG 1192, Topázio MG 1190 and Catucaí V. 20/15 Cv. 626 of medium maturity. The yield ranged from $44.4 \mathrm{sc} / \mathrm{ha}$ to $45.9 \mathrm{sc} / \mathrm{ha}$.

Group three (g) included seven progenies/ cultivars: Tupi IAC 1669-33 of early maturation, the progenies/cultivars Catucaí A. 24/137 (Seleção CAK) and Catucaí-açú (Fruto grande) of medium maturity, Catuaí V. IAC-81, Catuaí V. IAC-99 and Catuaí A. IAC-39 of late maturation time and Obatã V. IAC $1669-20$ of very late maturation time. The productivity of this group ranged from $47.2 \mathrm{sc} / \mathrm{ha}$ to $48.6 \mathrm{sc} / \mathrm{ha}$. Costa et al. (2013), when evaluating the agronomic behavior of progenies/cultivars in Varginha (southern Minas Gerias, Brazil), verified the average yield in four harvests of 42.7, 41.4 and $41.1 \mathrm{sc} /$ ha for the progenies IBC-Palma 1, Catucaí V. 24/137 and Sabiá Tardio, respectively. Matiello et al. (2007) studied progenies with resistance to rust also in the southern region of Minas Gerais and verified after five harvests that Sabiá Tardio and Catucaí V. 24/137 stood out with yields of 39.6 and 31.8 sc/ha, respectively. Paiva et al. (2010), also in southern Minas Gerais, after six harvests observed the dominance of the cultivar Sabiá Tardio with a yield of $40.89 \mathrm{sc} / \mathrm{ha}$.

The present study showed that progenies/ cultivars were highly resistant to rust (Tupi IAC 1669-33 and Obatã V. IAC 1669-20), moderately resistant (Catucaí A. 24/137-CAK and Catucaíaçú) and susceptible (Catuaís V IAC-81 and IAC-99 and Catuaí A. IAC-39) did not differ significantly for the average yield of 10 harvests; Which can be explained by the good agronomic management of the crop.

In the second (g) group are seven progenies/ cultivars, including the progeny/cultivar Catucaí $785 \mathrm{Cv} .15$ with red fruits of very early maturation; medium maturity progenies/varieties: IBC- Palma 2 (Fruto Grande); Catucaí V. 24/137; Catucaí A. 24/137 Cv. 250 and Sabiá Cv. 708; late maturation Arara (Sarchimor A.) and the very late maturation Acauã. Productivity of this group ranged from $49.5 \mathrm{sc} / \mathrm{ha}$ to $51.9 \mathrm{sc} / \mathrm{ha}$. Carvalho et al. (2012) obtained an average yield during four harvests close to $45.0 \mathrm{sc} / \mathrm{ha}$ for the genotypes Catucaí A. 24/137, Sabiá Cv. 398 and IPR 103. 
TABLE 3 - Summary of the analysis of variance, means and coefficients of variation of productivities over ten years, for the five biennia and the average of 10 harvests, rust infection (\%) of 05 harvests, yield, sieve 17 and above and plant vigor of the progenies/cultivars of Arabica coffee in the experiment installed at the "Sítio Santa Maria" farm, in Marechal Floriano, ES.

MEDIUM SQUARE - Productivity (sc/ha)

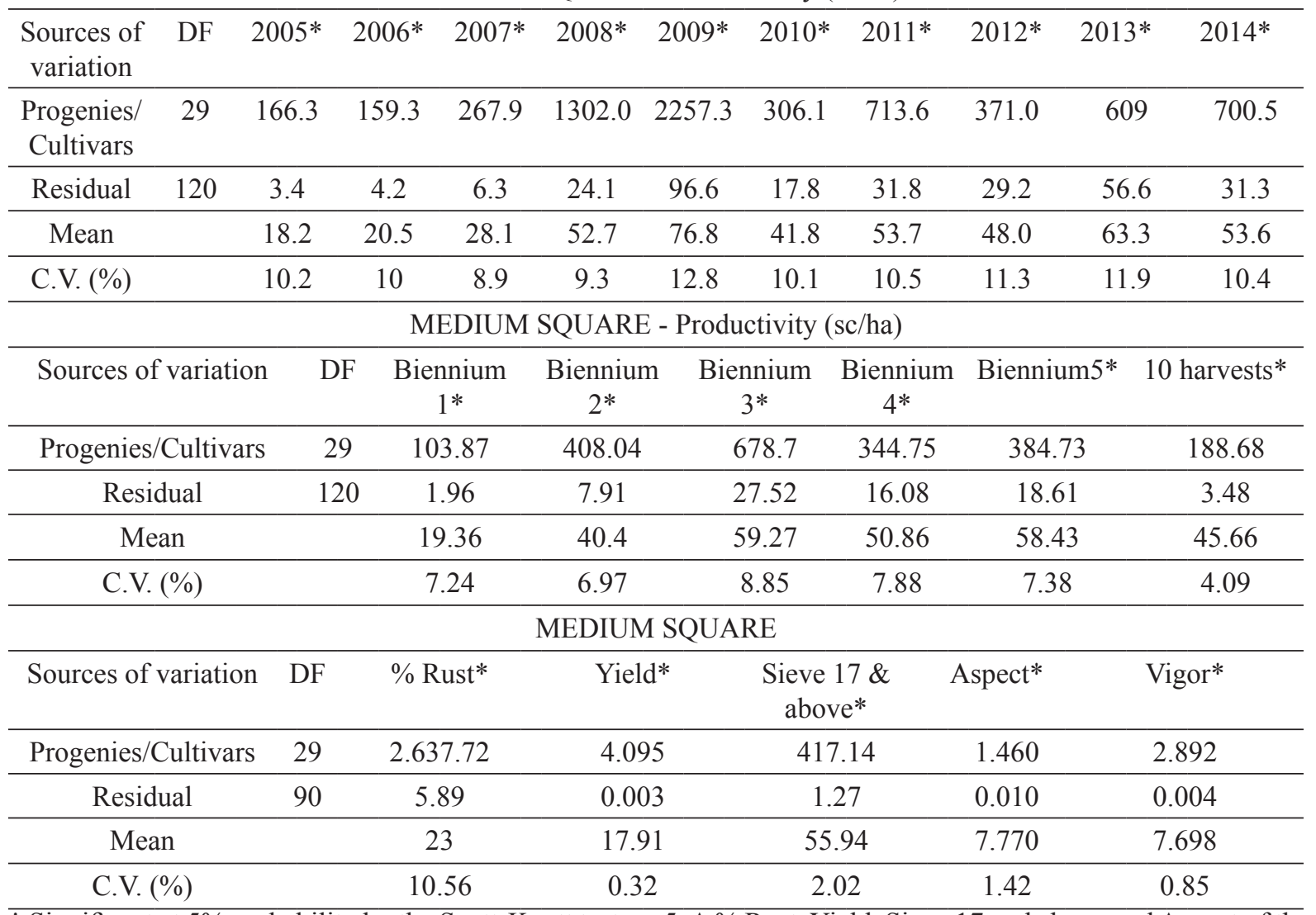

* Significant at 5\% probability by the Scott-Knott test. $n=5$. A \% Rust, Yield, Sieve 17 and above and Aspect of the grains was performed in harvests $(2005,2006,2007,2008$ and 2009) and Plant Vigor for the 10 harvests.

TABLE 4 - Mean productivity (sc/ha) of Arabica coffee progenies and cultivars during five biennia (2005 to 2014), the mean of 10 harvests (Mean sc/ha) and the relative percentage (\%) in the experiment installed in the farm "Sítio Santa Maria", in Marechal Floriano, ES.

\begin{tabular}{|c|c|c|c|c|c|c|c|c|}
\hline \multirow[t]{2}{*}{ Progenies/Cultivars } & \multirow[t]{2}{*}{ Maturation time } & \multicolumn{5}{|c|}{ Productivity per Biennia (sc/ha) } & \multirow{2}{*}{$\begin{array}{l}\text { Mean } \\
\text { (sc/ha) }\end{array}$} & \multirow{2}{*}{$\begin{array}{c}\% \\
\text { Relative }\end{array}$} \\
\hline & & $1^{\circ}$ & $2^{\circ}$ & $3^{\circ}$ & $4^{\circ}$ & $5^{\circ}$ & & \\
\hline Catucaí 785 Cv. 15 & Very early & $19.1 \mathrm{e}$ & $48.8 \mathrm{f}$ & $71.7 \mathrm{e}$ & $63.5 \mathrm{~d}$ & $56.2 \mathrm{c}$ & $51.9 \mathrm{~h}$ & 116.9 \\
\hline Tupi IAC 1669-33 & Early & $15.2 \mathrm{c}$ & $49.8 \mathrm{f}$ & $58.7 \mathrm{c}$ & $50.8 \mathrm{c}$ & $61.8 \mathrm{~d}$ & $47.2 \mathrm{~g}$ & 106.3 \\
\hline Katipó & Early & $16.9 \mathrm{~d}$ & $34.0 \mathrm{~b}$ & $56.2 \mathrm{~b}$ & $46.3 \mathrm{~b}$ & $56.9 \mathrm{c}$ & $42.0 \mathrm{e}$ & 94.6 \\
\hline Caturra A. Colombiano & Early & $21.3 \mathrm{f}$ & $46.2 \mathrm{e}$ & $50.4 \mathrm{~b}$ & $48.4 \mathrm{~b}$ & $43.2 \mathrm{a}$ & $41.9 \mathrm{e}$ & 94.4 \\
\hline Iapar 59 & Early & $16.2 \mathrm{~d}$ & $34.4 \mathrm{~b}$ & $61.8 \mathrm{c}$ & $37.3 \mathrm{a}$ & $38.7 \mathrm{a}$ & $37.7 \mathrm{~d}$ & 84.9 \\
\hline Caturra A. (Sel. CAK) & Early & $29.5 \mathrm{i}$ & $37.7 \mathrm{c}$ & $30.2 \mathrm{a}$ & $39.1 \mathrm{a}$ & $43.4 \mathrm{a}$ & $35.9 \mathrm{c}$ & 80.9 \\
\hline Caturra A. (Sel. Nanicão) & Early & $14.6 \mathrm{c}$ & $36.3 \mathrm{c}$ & $36.9 \mathrm{a}$ & $34.4 \mathrm{a}$ & $44.2 \mathrm{a}$ & $33.3 \mathrm{~b}$ & 75.0 \\
\hline Catucaí A. 2SL (Sel. CAK) & Medium & $24.6 \mathrm{~g}$ & $52.4 \mathrm{f}$ & $71.5 \mathrm{e}$ & $59.9 \mathrm{~d}$ & $65.4 \mathrm{e}$ & $54.7 \mathrm{i}$ & 123.2 \\
\hline Sabiá Cv. 708 & Medium & $23.2 \mathrm{f}$ & $63.3 \mathrm{~g}$ & $75.2 \mathrm{e}$ & $39.6 \mathrm{a}$ & $55.6 \mathrm{c}$ & $51.4 \mathrm{~h}$ & 115.8 \\
\hline
\end{tabular}




\begin{tabular}{|c|c|c|c|c|c|c|c|c|}
\hline Catucaí A. 24/137 Cv. 250 & Medium & $21.7 \mathrm{f}$ & $39.9 \mathrm{~d}$ & $81.1 \mathrm{f}$ & $51.0 \mathrm{c}$ & $62.7 \mathrm{~d}$ & $51.3 \mathrm{~h}$ & 115.5 \\
\hline Catucaí V. 24/137 & Medium & $27.3 \mathrm{~h}$ & $41.6 \mathrm{~d}$ & $61.2 \mathrm{c}$ & $57.1 \mathrm{c}$ & $66.3 \mathrm{e}$ & $50.7 \mathrm{~h}$ & 114.2 \\
\hline IBC-Palma 2 (Fruto grande) & Medium & $16.8 \mathrm{~d}$ & $41.5 \mathrm{~d}$ & $67.2 \mathrm{~d}$ & $61.2 \mathrm{~d}$ & $61.0 \mathrm{~d}$ & $49.5 \mathrm{~h}$ & 111.5 \\
\hline Catucaí-açú (Fruto grande) & Medium & $17.7 \mathrm{e}$ & $52.4 \mathrm{f}$ & $61.7 \mathrm{c}$ & $55.5 \mathrm{c}$ & $52.3 \mathrm{~b}$ & $47.9 \mathrm{~g}$ & 107.9 \\
\hline Catucaí A. 24/137 (Sel. CAK) & Medium & $27.2 \mathrm{~h}$ & $35.5 \mathrm{c}$ & $59.9 \mathrm{c}$ & $53.5 \mathrm{c}$ & $60.5 \mathrm{~d}$ & $47.3 \mathrm{~g}$ & 106.5 \\
\hline Catucaí V.20/15 Cv. 626 & Medium & $15.2 \mathrm{c}$ & $35.0 \mathrm{c}$ & $68.0 \mathrm{~d}$ & $45.5 \mathrm{~b}$ & $66.1 \mathrm{e}$ & $45.9 \mathrm{f}$ & 103.4 \\
\hline Topázio MG 1190 & Medium & $22.2 \mathrm{f}$ & $41.3 \mathrm{~d}$ & $54.2 \mathrm{~b}$ & $48.4 \mathrm{~b}$ & $62.5 \mathrm{~d}$ & $45.7 \mathrm{f}$ & 102.9 \\
\hline Rubi MG 1192 & Medium & $19.4 \mathrm{e}$ & $41.9 \mathrm{~d}$ & $51.0 \mathrm{~b}$ & $53.1 \mathrm{c}$ & $62.8 \mathrm{~d}$ & $45.6 \mathrm{f}$ & 102.7 \\
\hline Catucaí V. 36/6 & Medium & $20.4 \mathrm{f}$ & $36.6 \mathrm{c}$ & $55.9 \mathrm{~b}$ & $51.8 \mathrm{c}$ & $62.6 \mathrm{~d}$ & $45.5 \mathrm{f}$ & 102.5 \\
\hline Catucaí A. (Fruto grande) & Medium & $20.2 \mathrm{f}$ & $45.0 \mathrm{e}$ & $54.0 \mathrm{~b}$ & $48.3 \mathrm{~b}$ & $56.5 \mathrm{c}$ & $44.8 \mathrm{f}$ & 100.9 \\
\hline Catucaí A. Cv. 07 - SSP & Medium & $17.2 \mathrm{~d}$ & $36.7 \mathrm{c}$ & $51.7 \mathrm{~b}$ & $53.7 \mathrm{c}$ & $53.9 \mathrm{c}$ & $42.6 \mathrm{e}$ & 95.9 \\
\hline Mundo Novo 379-19 & Medium & $11.2 \mathrm{~b}$ & $33.1 \mathrm{~b}$ & $50.4 \mathrm{~b}$ & $44.9 \mathrm{~b}$ & $56.1 \mathrm{c}$ & $39.2 \mathrm{~d}$ & 88.3 \\
\hline Paraíso A. MG H 419-1 & Medium & $7.7 \mathrm{a}$ & $14.0 \mathrm{a}$ & $34.7 \mathrm{a}$ & $38.2 \mathrm{a}$ & $42.2 \mathrm{a}$ & $27.4 \mathrm{a}$ & 61.7 \\
\hline Catucaí V. 19/08 Cv. 380 & Late & $21.6 \mathrm{f}$ & $39.0 \mathrm{~d}$ & $74.4 \mathrm{e}$ & $66.7 \mathrm{~d}$ & $66.4 \mathrm{e}$ & $53.8 \mathrm{i}$ & 121.2 \\
\hline Arara (Sarchimor A.) & Late & $18.5 \mathrm{e}$ & $33.9 \mathrm{~b}$ & $66.1 \mathrm{~d}$ & $57.2 \mathrm{c}$ & $75.7 \mathrm{f}$ & $50.3 \mathrm{~h}$ & 113.3 \\
\hline Catuaí A. IAC-39 & Late & $21.4 \mathrm{f}$ & $49.0 \mathrm{f}$ & $58.5 \mathrm{c}$ & $54.4 \mathrm{c}$ & $59.5 \mathrm{~d}$ & $48.6 \mathrm{~g}$ & 109.5 \\
\hline Catuaí V. IAC-99 & Late & $21.9 \mathrm{f}$ & $37.2 \mathrm{c}$ & $65.3 \mathrm{~d}$ & $54.7 \mathrm{c}$ & $59.8 \mathrm{~d}$ & $47.8 \mathrm{~g}$ & 107.7 \\
\hline Catuaí V. IAC-81 & Late & $19.6 \mathrm{e}$ & $51.3 \mathrm{f}$ & $55.6 \mathrm{~b}$ & $47.8 \mathrm{~b}$ & $61.7 \mathrm{~d}$ & $47.2 \mathrm{~g}$ & 106.3 \\
\hline Catuaí V. IAC-44* & Late & $17.8 \mathrm{e}$ & $33.2 \mathrm{~b}$ & $61.7 \mathrm{c}$ & $42.8 \mathrm{~b}$ & $66.3 \mathrm{e}$ & $44.4 \mathrm{f}$ & 100.0 \\
\hline Acauã & Very late & $16.9 \mathrm{~d}$ & $40.8 \mathrm{~d}$ & $65.5 \mathrm{~d}$ & $62.9 \mathrm{~d}$ & $68.8 \mathrm{e}$ & $50.9 \mathrm{~h}$ & 114.6 \\
\hline Obatã V. IAC 1669-20 & Very late & $18.3 \mathrm{e}$ & $30.3 \mathrm{~b}$ & $67.6 \mathrm{~d}$ & $57.6 \mathrm{c}$ & $63.9 \mathrm{e}$ & $47.6 \mathrm{~g}$ & 107.2 \\
\hline
\end{tabular}

A study carried out by Dias et al. (2005) with 25 coffee progenies also verified a high productive performance of the progeny Sarchimor IAC-4361 with yield of $44.7 \mathrm{sc} / \mathrm{ha}$. A study by Costa et al. (2012) confirmed that after four harvests the progeny Arara planta 418 (Sarchimor A.) obtained an average of 50.2 sacks/ha. The progenies / cultivars of the present study can reach very close productivities and up to 50.0 beneficiated sacks / hectare, regardless of the maturation period. This is very important for coffee growers in order to better manage and scale the harvesting workforce and the physical postharvest structure, as well as to obtain a larger volume of peeled cherry coffee.

In the first (i) group the Catucaí V. 19/08 Cv. 380 progeny was highlighted with productivity of $53.8 \mathrm{sc} / \mathrm{ha}$, being that of greatest productivity for the late maturation time, and the progeny Catucai A. 2 SL (selection CAK) with productivity of $54.7 \mathrm{sc} / \mathrm{ha}$ which was the progeny of greatest productivity for the medium maturation period.

Comparing the yield of the control variety/ progeny (44.4 sc/ha) with the others, it was possible to observe that 21 varieties/progenies were superior, namely: very early maturation Catucaí 785 Cv. 15; early maturation Tupi IAC 1669-33; medium maturation Catucaí A. 2 SL (Sel. CAK), Sabiá Cv. 708, Catucaí A. 24/137 Cv. 250, Catucaí V. 24/137, IBC-Palma 2 (Fruto grande), Catucaí-açú (Fruto grande) and Catucaí A. 24/137 (Sel. CAK), Catucaí V.20/15 Cv. 626, Topázio MG 1190, Rubi MG 1192, Catucaí V. 36/6 and Catucaí A. (Fava grande); late maturation Catucaí V. 19/08 Cv. 380, Arara (Sarchimor A.), Catuaí A. IAC-39, Catuaí V. IAC-99 and Catuaí V. IAC-81and very late maturation Acauã and Obatã V. IAC 1669-20 (Table 4).

The maturation period does not influence productivity since the varieties/progenies of the same maturation periods were present in different groups, where the varieties of group nine (a) were the less productive and those of group one (i) the most productive. This shows a collection of materials with genetic diversity of yellow and red fruits available to coffee growers with adaptation to conditions at elevations exceeding $700 \mathrm{~m}$ and cold climate. 


\section{Rust}

The progenies/cultivars with the lowest percentage of rust were: Acauã, Catucaí V. 19/08 Cv. 380, IBC-Palma 2 (Fruto grande), Iapar 59, Katipó, Arara (Sarchimor A.), Sabiá Cv. 708, Tupi IAC 1669-33, Caturra A. Colombiano, Catucaí 785 Cv.15, Catucaí V. 24/137 and Obatã V. IAC 1669-20. These varieties are distributed among the five different maturation seasons, which is very important for coffee growers to be able to stagger crops, lower production costs and increase profitability, as well as avoid using chemical control of the disease. Among the 30 progenies/cultivars evaluated, three cultivars were highlighted: Tupi IAC 1669-33 and Iapar 59 of early maturation and O Obatã V. IAC 1669-20 of very late maturation; and the progenies Katipó of early maturation; Catucaí V. 19/08 Cv. 380 and Arara (Sarchimor A.) of late maturation and Acauã of very late maturation that showed no incidence of rust. The greatest incidences of rust were the found in the progenies Caturra A. (Sel. CAK) and Mundo Novo 379-19 with mean incidences of rust of $80.15 \%$ and $85.5 \%$, respectively (Table 5).

The severity of rust can vary in Arabica coffee genotypes even when grown under the same environmental conditions, with different levels of fungus resistance, classifying the genotypes as tolerant or susceptible (REUBEN \& MTENGA, 2012); resistance is controlled by the SH gene and also by other genes, but with less effect (FAZUOLI et al., 2007). In fields competing with Arabica cultivars, certain cultivars present complete resistance to rust, while others may lose resistance due to local environmental conditions (SHIGUEOKA et al., 2014), a fact that is proven in this study. Because densified cropping favors the attack of rust, Paiva et al. (2010) indicated that care must be taken in the recommendation of cultivars for densified systems. According to Cabral et al. (2016), the inoculum source is easily dispersed by wind across great distances, which allows for dispersion of the pathogen among coffee growing areas in Brazil, and it is therefore difficult to predict the durability of resistance sources to coffee rust. For this reason it is recommended that breeding programs therefore incorporate multigene resistance as a control strategy.

\section{Plant vigor}

The progenies/cultivars with the lowest plant vigor scores were Caturra A. (Sel. CAK), Caturra A. (Sel. Nanicão) and the cultivar Mundo
Novo 379-19, with values of 5.06, 5.89 and 6.65 , respectively. The highest scores for vigor with average greater than 9.0 were the progenies Catucaí V. 19/08 Cv. 380 of late maturity with score of 9.01, Arara (Sarchimor A.) with score of 9.08 and Acauã with score of 9.15 , both of late maturation (Table 5). One of the characteristics observed in the field for plant vigor is defoliation caused by the incidence of rust attack. It was observed that the progenies presenting the best scores for vigor are grouped with the lowest percentages of rust attack incidence, those with averages of 10 harvests presented $0.00 \%$ disease attack. Genetic materials with high plant vigor are correlated with increased productivity of the cultivars (SEVERINO et al., 2002), which may improve nutrient uptake, reduce suffering under unfavorable edaphoclimatic conditions (PETEK et al., 2002) and increase the longevity of crops in the field associated with the cultivars "Sarchimor" and "Catimor" (MATIELLO et al., 2005).

\section{Yield, Sieve and Appearance}

The lowest average yield of the coffee progenies/cultivars was that of Paraíso A. MG $\mathrm{H}$ 419-1, with average yield of $15.35 \mathrm{~kg}$ of processed coffee $/ 36 \mathrm{~kg}$ sac of coffee beans, while cultivar Tupi IAC 1669-33 presented the maximum of $19.84 \mathrm{~kg}$. Sieve 17 and above (coarse flat) is a required feature in the international coffee trade. For this attribute it was also observed that the lowest average was for the cultivar Paraíso A. MG H 419-1 with only $32.68 \%$ of sieve 17 and above. The progeny Catucaí A. 24/137 (Sel. CAK) presented $68.48 \%$ of the grains classified presenting this characteristic (Table 5).

The aspect of green coffee beans is widely used by coffee traders on the national and international market. Of the progenies/ cultivars studied, 11 genetic materials had the worst scores, varying between 7.05 and 7.12 and the best cultivars Catucaí A. 2 SL (Sel. CAK), Mundo Novo 379-19 and Catucaí A. 24/137 (Sel. CAK)) presented scores of $8.85,8.97$ and 9.07, respectively (Table 5).

The commercial quality of coffee is based on characteristics such as appearance, color and cupping (Carvalho et al., 1994), in which current world demand is for coffees of both the best visual appearance and high sensorial quality, with preference for genotypes with higher percentage of coarse flat grains and better sensorial quality of the drink (PEROSA \& ABREU, 2009; GICHIMU et al., 2012). 
TABLE 5 - Mean rust infection (\%), Yield, Sieve 17 and above and Aspect of 05 growing seasons (2005 to 2009) and Plant vigor of 10 seasons (2005 to 2014) of the Arabica coffee progenies/cultivars installed at the experimental farm "Sítio Santa Maria", in Marechal Floriano, ES, Brazil.

\begin{tabular}{|c|c|c|c|c|c|c|}
\hline Progenies/Cultivars & Maturation period & $\begin{array}{l}\text { Rust } \\
(\%)\end{array}$ & Vigor & Yield & $\begin{array}{c}\text { Sieve } 17 \\
\text { and above }\end{array}$ & Aspect \\
\hline Catucaí 785 Cv. 15 & Very early & $3.55 \mathrm{a}$ & $8.11 \mathrm{~h}$ & $17.75 \mathrm{~h}$ & $65.60 \mathrm{k}$ & $8.10 \mathrm{c}$ \\
\hline Tupi IAC 1669-33 & Early & $0.00 \mathrm{a}$ & $7.94 \mathrm{~g}$ & $19.84 \mathrm{r}$ & $65.24 \mathrm{k}$ & $8.08 \mathrm{c}$ \\
\hline Katipó & Early & $0.00 \mathrm{a}$ & $7.55 \mathrm{e}$ & $17.72 \mathrm{~h}$ & $58.80 \mathrm{~h}$ & $7.08 \mathrm{a}$ \\
\hline Caturra A. Colombiano & Early & $3.20 \mathrm{a}$ & $7.89 \mathrm{~g}$ & $18.62 \mathrm{n}$ & $32.76 \mathrm{a}$ & $8.07 \mathrm{c}$ \\
\hline Iapar 59 & Early & $0.00 \mathrm{a}$ & $6.73 \mathrm{~d}$ & $17.94 \mathrm{j}$ & $60.96 \mathrm{i}$ & $8.05 \mathrm{c}$ \\
\hline Caturra A. (Sel. CAK) & Early & $80.15 \mathrm{i}$ & $5.06 \mathrm{a}$ & $19.71 \mathrm{q}$ & $42.84 \mathrm{~b}$ & $7.12 \mathrm{a}$ \\
\hline Caturra A. (Sel. Nanicão) & Early & $60.20 \mathrm{~h}$ & $5.89 \mathrm{~b}$ & $18.40 \mathrm{~m}$ & $52.16 \mathrm{e}$ & $7.07 \mathrm{a}$ \\
\hline Catucaí A. 2 SL (Sel. CAK) & Medium & $21.55 \mathrm{~d}$ & $8.16 \mathrm{~h}$ & $18.79 \mathrm{o}$ & $62.92 \mathrm{j}$ & $8.85 \mathrm{~d}$ \\
\hline Sabiá Cv. 708 & Medium & $1.80 \mathrm{a}$ & $7.71 \mathrm{f}$ & $18.96 \mathrm{p}$ & $64.68 \mathrm{k}$ & $7.85 \mathrm{~b}$ \\
\hline Catucaí A. 24/137 Cv. 250 & Medium & $15.00 \mathrm{c}$ & $8.08 \mathrm{~h}$ & $18.99 \mathrm{p}$ & $62.56 \mathrm{j}$ & $7.78 \mathrm{~b}$ \\
\hline Catucaí V. 24/137 & Medium & $3.65 \mathrm{a}$ & $7.89 \mathrm{~g}$ & 18.78 o & $54.04 \mathrm{f}$ & $7.12 \mathrm{a}$ \\
\hline IBC-Palma 2 (Fruto grande) & Medium & $0.00 \mathrm{a}$ & $7.94 \mathrm{~g}$ & $18.09 \mathrm{k}$ & $56.92 \mathrm{~g}$ & $7.07 \mathrm{a}$ \\
\hline Catucaí-açú (Fava grande) & Medium & $12.65 \mathrm{c}$ & $7.93 \mathrm{~g}$ & $18.01 \mathrm{j}$ & $47.16 \mathrm{~d}$ & $7.07 \mathrm{a}$ \\
\hline Catucaí A. 24/137 (Sel. CAK) & Medium & $43.50 \mathrm{f}$ & $7.75 \mathrm{f}$ & $17.84 \mathrm{i}$ & 68.481 & $9.07 \mathrm{e}$ \\
\hline Catucaí V.20/15 Cv. 626 & Medium & $15.00 \mathrm{c}$ & $7.78 \mathrm{f}$ & $17.85 \mathrm{i}$ & $56.12 \mathrm{~g}$ & $7.08 \mathrm{a}$ \\
\hline Topázio MG 1190 & Medium & $52.70 \mathrm{~g}$ & $8.03 \mathrm{~g}$ & $17.08 \mathrm{e}$ & $42.64 \mathrm{~b}$ & $8.08 \mathrm{c}$ \\
\hline Rubi MG 1192 & Medium & $45.90 \mathrm{f}$ & $7.78 \mathrm{f}$ & $17.85 \mathrm{i}$ & $45.16 \mathrm{c}$ & $8.08 \mathrm{c}$ \\
\hline Catucaí V. 36/6 & Medium & $8.85 \mathrm{~b}$ & $7.83 \mathrm{f}$ & $18.01 \mathrm{j}$ & $61.20 \mathrm{i}$ & $7.05 \mathrm{a}$ \\
\hline Catucaí A. (Fava grande) & Medium & $24.45 \mathrm{~d}$ & $8.08 \mathrm{~h}$ & $17.46 \mathrm{~g}$ & $66.16 \mathrm{k}$ & $8.05 \mathrm{c}$ \\
\hline Catucaí A. Cv. 07 - SSP & Medium & $8.70 \mathrm{~b}$ & $7.98 \mathrm{~g}$ & $15.75 b$ & $60.68 \mathrm{i}$ & $7.08 \mathrm{a}$ \\
\hline Mundo Novo 379-19 & Medium & $85.50 \mathrm{j}$ & $6.51 \mathrm{c}$ & $18.61 \mathrm{n}$ & $63.04 \mathrm{j}$ & $8.97 \mathrm{e}$ \\
\hline Paraíso A. MG H 419-1 & Medium & $6.75 \mathrm{~b}$ & $6.65 \mathrm{~d}$ & $15.35 \mathrm{a}$ & $32.68 \mathrm{a}$ & $8.05 \mathrm{c}$ \\
\hline Catucaí V. 19/08 Cv. 380 & Late & $0.00 \mathrm{a}$ & $9.01 \mathrm{i}$ & $17.69 \mathrm{~h}$ & $56.72 \mathrm{~d}$ & $7.12 \mathrm{a}$ \\
\hline Arara (Sarchimor A.) & Late & $0.00 \mathrm{a}$ & $9.08 \mathrm{i}$ & $17.47 \mathrm{~g}$ & $57.04 \mathrm{~g}$ & $7.85 \mathrm{~b}$ \\
\hline Catuaí A. IAC-39 & Late & $41.50 \mathrm{e}$ & $7.48 \mathrm{e}$ & $17.32 \mathrm{f}$ & $63.88 \mathrm{j}$ & $8.05 \mathrm{c}$ \\
\hline Catuaí V. IAC-99 & Late & $54.70 \mathrm{~g}$ & $7.54 \mathrm{e}$ & 18.321 & $66.60 \mathrm{k}$ & $8.10 \mathrm{c}$ \\
\hline Catuaí V. IAC-81 & Late & $51.75 \mathrm{~g}$ & $7.51 \mathrm{e}$ & 18.321 & $65.56 \mathrm{k}$ & $8.07 \mathrm{c}$ \\
\hline Catuaí V. IAC-44* & Late & $39.20 \mathrm{e}$ & $7.69 \mathrm{f}$ & $17.71 \mathrm{~h}$ & $65.00 \mathrm{k}$ & $8.07 \mathrm{c}$ \\
\hline Acauã & Very late & $0.00 \mathrm{a}$ & $9.15 \mathrm{k}$ & $16.77 \mathrm{~d}$ & $43.88 \mathrm{~b}$ & $7.07 \mathrm{a}$ \\
\hline Obatã V. IAC 1669-20 & Very late & $0.00 \mathrm{a}$ & $8.26 \mathrm{i}$ & $16.15 \mathrm{c}$ & $64.72 \mathrm{k}$ & $8.03 \mathrm{c}$ \\
\hline
\end{tabular}

Means followed by the same letter in the same column do not differ at 5.0\% probability according to the ScottKnott test $(\mathrm{n}=5)$. *Progeny/Cultivar used as the control. A \% Rust, Yield, Sieve 17 and above and Aspect of the grains was assess in the growing seasons (2005, 2006, 2007, 2008 and 2009) and Plant Vigor in 10 seas

Because the bean size is directly related to coffee quality and improves the visual aspect, this is one of the criteria for selection of genotypes of a new cultivar and should be used in coffee breeding studies (PAIVA et al., 2010; PEDRO et al., 2011).
With the difficulty and high costs of the labor force that Brazilian coffee producers are facing, the harvest yield is an important aspect when considering manual harvest, a technique practiced by the great majority of small-scale agricultural 
producers. It was observed that the highest yield is obtained for short and conical sized plants, as is the case of Catucaí A. 2 SL and Catucaí V. 19/08 (Japi) of medium and late maturity, respectively.

In relation to the set of desirable agronomic characteristics that a progeny/cultivar should have, including: productivity, vigor, yield, high sieve and low susceptibility to rust, it is observed in Figure 1 that producers have access to good genetic material for the 05 different maturation periods. For example, the progeny / cultivar Paraíso A. MG H 419-1 present tolerance / resistance to rust, but doesn't show good productivity when compared to Catucaí A. 2 SL (Sel. CAK) and Tupi IAC 166933 that show good productivity, good sieve 17 and above, good yield and good harvest sacks / day besides presenting resistance to rust. Moreover, the progeny / cultivar Caturra A. (Sel. CAK); Caturra A. (Sel. Nanicão); Mundo Novo 379-19, should be avoided because they are susceptible to rust. (Figure 1).

According to Carvalho et al (2011), the progeny / cultivar Paraíso A. MG H 4191 presenting high resistance to rusty and good productivity, however this progeny presented low productivity in relation to the other progenies evaluated in this present work.

\section{CONCLUSIONS}

When relating productivity with the maturation period we can highlight the progenies/ cultivars: i) of very early maturation: Catucaí 78515 ; ii) of early maturation: Tupi IAC 1669-33; iii) of medium maturation the progenies: Catucaí A. 2 SL (Sel. CAK), Sabiá Cv. 708, Catucaí A. 24/137 Cv.250, Catucaí V. 24/137, IBC-Palma 2 (Fruto grande), Catucaí-açú (Fruto grande) and Catucaí A. 24/137 (Sel. CAK); iv) of late maturation: Catucaí V. 19/08 Cv. 380 and Arara (Sarchimor A.) and v) of very late maturation Acauã and Obatã V. IAC 1669-20.

Coffee progenies/cultivars with tolerance and/or resistance to rust are excellent options for planting in new or renewal areas in humid and high elevation conditions to obtain high productivity and high plant vigor, potentially eliminating the need for chemical control of rust.

Therefore, this study shows that for the 5 different maturation periods studied, in areas of crop renewal or even for the conditions of new experimental areas, coffee growers have several options with specific characteristics of each progeny/cultivar superior to the standard Catuaí most commonly cultivated in the region.

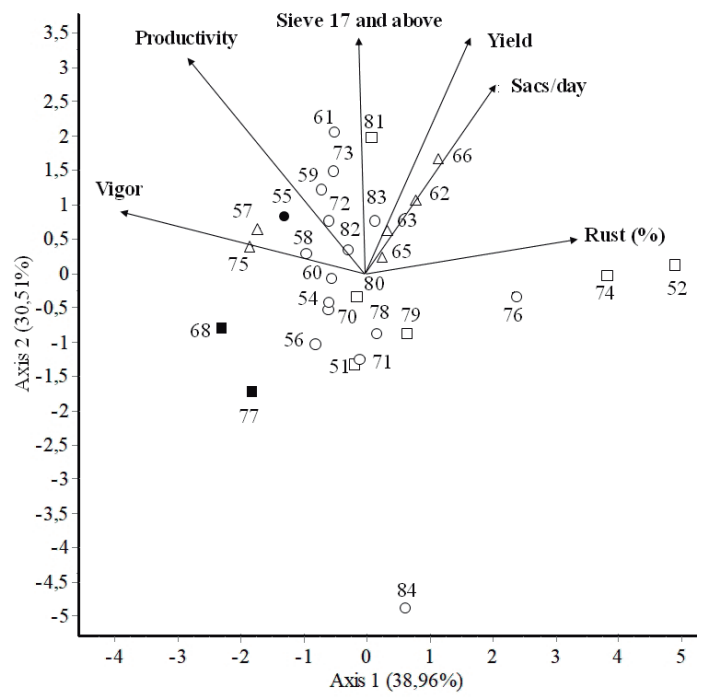

FIGURE 1 - Principal Components Analysis (PCA) relating the progenies/cultivars to the variables Plant vigor, Productivity (sc/ha), Sieve 17 and above, Harvest yield (sacs/day) and Rust (\% infection). Different symbols indicate different maturation periods: • very early; $\square$ early; $\circ$ medium; $\Delta$ late; $\square$ very late. The numbers represent the varieties: 51) Caturra A. Colombiano; 52) Caturra A. (Sel. CAK); 54) Catucaí-açú (Fruto grande); 55) Catucaí 785 Cv. 15; 56) Catucaí A. Cv. 07 - SSP; 57) Catucaí V. 19/08 Cv. 380; 58) Catucaí V. 24/137; 59) Catucaí A. 24/137 Cv. 250; 60) Catucaí V. 36/6; 61) Catucaí A. 2 SL (Sel. CAK); 62) Catuaí V. IAC-81; 63) Catuaí A. IAC39; 65) Catuaí V. IAC-44; 66) Catuaí V. IAC-99; 68) Acauã; 70) Catucaí V.20/15 Cv. 626; 71) Topázio MG 1190; 72) IBC-Palma 2 (Fruto grande); 73) Sabiá Cv. 708 ; 74) Caturra A. (Sel. Nanicão); 75) Arara (Sarchimor A.); 76) Mundo Novo 379-19; 77) Obatã V. IAC 1669-20; 78) Rubi MG 1192; 79) Iapar 59; 80) Katipó; 81) Tupi IAC 1669-33; 82) Catucaí A. (Fruto grande); 83) Catucaí A. 24/137 (Sel. CAK); 84) Paraíso A. MG H 419-1 


\section{REFERENCES}

ANDREAZI, E. et al. Desempenho de híbridos F1 de café arábica com resistência simultânea a ferrugem, mancha aureolada e bicho mineiro. Coffee Science, Lavras, v. 10, n .3, p. 375-382, jul/set. 2015.

CABRAL, P. G. C. et al. Genetic diversity and structure of Hemileia vastatrix populations on Coffea spp. Plant Pathology, v. 65, n. 2, p. 196-204, May. 2016.

CARVALHO, C. H. S. et al. Cultivares de café arábica de porte baixo. In: CARVALHO, C. H. S. de (Ed.). Cultivares de café: origem, características e recomendações. Brasília: Embrapa Café, 2008. cap. 9, p. 27-34.

CARVALHO, A. M. et al. Correlação entre crescimento e produtividade de cultivares de café em diferentes regiões de Minas Gerais, Brasil. Pesquisa Agropecuária Brasileira, Brasília, v. 45, n. 3, p. 269275, mar. 2010.

CARVALHO, C.H.S. Cultivares de café: origem, características e recomendações. Embrapa Café, Brasília. 2008. 334 p.

CARVALHO, A. M. et al. Desempenho agronômico de cultivares de café resistentes à ferrugem no Estado de Minas Gerais, Brasil. Bragantia, v. 71, n. 4, p. 481487, out/dez. 2012.

CARVAlHO, C. H. S. et al. Comportamento de cultivares de café com resistência à ferrugem-docafeeiro no sul do estado de Minas Gerais. In: VII Simpósio de Pesquisa dos Cafés do Brasil. 2011, AraxáMG. Resumos expandidos... Araxá-MG, agosto. 2011.

COSTA, J. C. et al. Comportamento agronômico de progênies e cultivares de cafeeiro com resistência específica à ferrugem. Coffee Science, Lavras, v. 8, n. 2, p. 183-191, abr/jun. 2013.

DIAS, F. P. et al. Caracterização de progênies do cafeeiro (Coffea arabica L.) selecionadas em Minas Gerais: caracteres relacionados à produção. Revista Ceres, Viçosa, v. 52, n. 299, p. 85-100, jan. 2005.

EMBRAPA. Sistema brasileiro de classificação de solos. 3. ed. Brasília, 2013. 353 p.

FAZUOLI, L.C. et al. A ferrugem alaranjada do cafeeiro e a obtenção de cultivares resistentes. O Agronômico, v. 59, n. 1, p. 48-53, 2007.
FERREIRA, D. F. Sisvar: a computer statistical analysis system. Ciência e Agrotecnologia, Lavras, v. 35, n. 6, p. 1039-1042, nov/dez. 2011.

GICHIMU B. M. et al. Selection within Coffea arabica cv. Ruiru 11 for high cup quality. African Journal of Food Science, v. 6, n. 18, p. 456-464, Sept. 2012.

GUERREIRO-FILHO, O. et al. Características utilizadas para a identificação de cultivares de café: In: CARVALHO, C. H. S. de (Ed.). Cultivares de café: origem, características e recomendações. Brasília: Embrapa Café, 2008. p. 141-156.

LIMA, P. C. Método de amostragem para a avaliação do índice de infecção da ferrugem do cafeeiro (Hemileia vastatrix, Berk. e Br.). 1979. 65 p. Dissertação (Mestrado em Estatística e Experimentação Agronômica) - Escola Superior de Agricultura "Luiz de Queiroz", Piracicaba, 1979.

MARTINS, M. Q. et al. Selection and validation of reference genes for accurate RT-qPCR data normalization in Coffea spp. under a climate changes context of interacting elevated $\left[\mathrm{CO}_{2}\right]$ and temperature. Frontiers in Plant Science, v. 8, p. 307, n. 1-11, Mar. 2017.

MARTINEZ, H. E. P.; TOMAZ, M. A.; SAKIYAMA, N. S. Guia de Acompanhamento das aulas de cafeicultura. Viçosa: UFV, 2007. 152 p.

MAtiello, J. B. et al. Cultura do café no Brasil. Manual de Recomendações. 7. ed. MAPA/Fundação Procafé. Rio de Janeiro, RJ e Varginha, MG, 2016, 584 p.

MATIELLO, J. B. et al. Comportamento de progênies de café com resistência a ferrugem-do-cafeeiro no sul do estado de Minas de Gerais. In: SIMPÓSIO DE PESQUISA DOS CAFÉS DO BRASIL, 5., 2007, Águas de Lindóia. Anais... Brasília: Embrapa/ Minasplan, 2007. CD-ROM.

MATIELlO, J. B.; ALMEIDA, S. R.; CARVALHO, C. H. S. Resistant cultivars to coffee leaf rust. In: ZAMBOLIM, L.; ZAMBOLIM, E. M.; VÁRZEA, V. M. P. Durable Resistance to Coffee Leaf Rust. Viçosa: UFV, 2005. p. 443-445.

NASCIMENTO, M. et al. Adaptabilidade e estabilidade via regressão não paramétrica em genótipos de café. Pesquisa Agropecuária Brasileira, Brasília, v. 45, n. 1, p. 41-48, jan. 2010. 
OLIVEIRA, D. R. et al. Caracterização agronômica de cultivares de café arábica portadoras de fatores de resistência à ferrugem. In: IX Simpósio de Pesquisa dos Cafés do Brasil. 2015. Curitiba-PR. Anais... CuritibaPR, junho. 2015.

PAIVA, R. N. et al. Comportamento agronômico de progênies de cafeeiro (Coffea arabica L.) em Varginha, MG. Coffee Science, Lavras, v. 5, n. 1, p. 49-58, jan/ abr. 2010 .

PAIVA, B. R. T. L. et al. Progress of rust in coffee plants in various densities of cultivation in irrigated planting after pruning. Ciência e Agrotecnologia, Lavras, v. 35, n. 1, p. 137-143, jan/fev. 2011.

PARTELLI, F.L. et al. Low temperature impact on photosynthetic parameters of coffee genotypes. Pesquisa Agropecuária Brasileira, Brasília, v. 44, n. 11, p. 1404-1415, Nov. 2009.

PEDRO, F. C. et al. Comportamento agronômico de progênies F4 de cafeeiros oriundos do cruzamento entre os cultivares Mundo Novo e Catuaí. Revista Ceres, Viçosa, v. 58, n. 3, p. 315-322, maio/jun. 2011.

PEROSA, J. M. Y.; ABREU, L. H. F. Aspectos econômicos e oportunidades no mercado de cafés de qualidade. Pesquisa Agropecuária Tropical, Goiás, v. 39, n. 2, p. 144-150, abr/jun. 2009.

PETEK, M. R. et al. Análise de trilha entre caracteres agronômicos e dano de geada, em progênies derivadas do cruzamento "Vila Sarchi" x "Híbrido de Timor". SBPN - Scientific Journal, v. 6, p. 37-39, 2002. (Ed. Especial).
PREZOTTI, L. C. et al. Manual de recomendação de calagem e adubação para o estado do Espírito Santo: $\mathbf{5}^{\mathrm{a}}$ aproximação. Vitória: SEEA, 2007. 305 p.

REUBEN, S. O. W. M.; MTENGA, D. J. I. Variation in resistance to coffee leaf rust (Hemileia vastatrix, Berk. and Broome) among germplasm progenitors at the Tanzanian Coffee Research Institute (TACRI). International Journal of Agricultural Sciences, v. 2, p. 296-300, 2012.

RODRIGUES, W. P. et al. Agronomic performance of arabica coffee genotypes in northwest Rio de Janeiro State. Genetics and Molecular Research, v. 13, n. 3, p. 5664-5673, July. 2014.

RODRIGUES, W. P. et al. Assessment of genetic divergence among coffee genotypes by Ward-MLM procedure in association with mixed models. Genetics and Molecular Research, v. 15, n. 2, p. 1-7. 2016.

SERA, G. H. et al. Identificação de progênies de café arábica portadoras de genes de Coffea racemosa com ciclo de maturação dos frutos precoce. In: IX Simpósio de Pesquisa dos Cafés do Brasil. 2015, Curitiba-PR. Anais... Curitiba-PR, junho. 2015

SEVERINO, L. S. et al. Associações da produtividade com outras características agronômicas de café (Coffea arabica L. "Catimor"). Acta Scientiarum, Maringá, v. 24, n. 5, p. 1467-1471. 2002

SHIGUEOKA, L. H. et al. Selection of Arabic coffee progenies with rust resistance. Crop Breeding and Applied Biotechnology, Viçosa, v. 14, n. 2, p. 88-93, June. 2014.

ZAMBOLIM, L.; VALE, F. X. R.; ZAMBOLIM, E. M. Doenças do cafeeiro. In: KIMATI, H. et al. Manual de fitopatologia: doenças das plantas cultivadas. 4 . ed. Piracicaba: Ceres, 2005. v. 2. p. 165-180. 